\title{
BioLink
}

Jurnal Biologi Lingkungan, Industri, Kesehatan

Available online http://ojs.uma.ac.id/index.php/biolink

\section{THE EFFECT OF TAMARIND (TAMARINDUS INDICA) LEAF EXTRACT OINTMENT IN CONTROLLING THE GROWTH OF THE BACTERIA PROPIONIBACTERIUM ACNES THAT TRIGGERS ACNE}

\section{Hasna Azzahra, Fianicha Shalihah, Indah Nurlita Trisnawati, Siti Aeniah, Lintang Prima Cahyani, \& Alanindra Saputra*}

Biology Education, Faculty of Teacher Training and Education, Universitas Sebelas Maret, Indonesia

Submited : 11-08-2021; Reviewed :19-09-2021; Accepted : 26-01-2022

*Corresponding author: E-mail : alanindra@staff.uns.ac.id

\begin{abstract}
Tamarind (Tamarindus indica) is a versatile plant, findable in Indonesia (Java, Bali, North Sumatra, West Kalimantan, and South Sulawesi). The leaves are green to brown, round, 1-2.5 cm long and 4-8 $\mathrm{mm}$ wide, rounded tips, rounded base of blades, and flat edges. The content contained in tamarind leaves such as flavonoids, tannins, saponins, and alkaloids is believed to inhibit Propionibacterium acnes activity. This study aims to determine the effect of tamarind leaf extract ointment in controlling the growth of the bacteria Propionibacterium acnes that triggers acne. This study applied a Completely Randomized Design with 96\% ethanol maceration method. Propionibacterium acnes was evidenced by the inhibition zone formed. The diameter of the inhibition zone of the $25 \%$ ointment was $1.235 \mathrm{~cm}$, the $30 \%$ concentration was $1.385 \mathrm{~cm}$, the $35 \%$ concentration was 1,680 cm, and the ointment base was $0 \mathrm{~cm}$. The ANOVA test showed a significant value of $0.000<0.05$, so there was a significant difference between the inhibition zone and the 95\% confidence level. The results of Post Hoc test were P<0.05, meaning that there was a significant difference between the bases with formulas 1, 2, and 3. Thus, tamarind leaf extract ointment had a strong inhibitory effect on Propionibacterium acnes.
\end{abstract}

Keywords: Tamarind; Ointment,; Acne; Propionibacterium acnes

How to Cite: Azzahra, H., Shalihah, F., Trisnawati, I.N., Aeniah, S., Cahyani, L.P., \& Saputra, A. (2022). The Effect Of Tamarind (Tamarindus indica) Leaf Extract Ointment In Controlling The Growth Of The Bacteria Propionibacterium acnes That Triggers Acne, BioLink: Jurnal Biologi Lingkungan, Industri dan Kesehatan, Vol. 8 (2): Hal. 207-217 
Azzahra, H., Shalihah, F., Trisnawati, I.N., Aeniah, S., Cahyani, L.P., \& Saputra, A. The Effect Of Tamarind (Tamarindus indica) Leaf Extract Ointment In Controlling The Growth Of The Bacteria Propionibacterium acnes That Triggers Acne

\section{INTRODUCTION}

Skin health is something that is considered very important for everyone, especially teenagers. Therefore, they compete to always maintain healthy skin to avoid skin diseases. One of the problems with skin health is acne (Lestari et al., 2021). Acne (Acne vulgaris) is a skin disorder caused by Staphylococcus aureus and Propionibacterium acnes bacteria. This disorder can affect anyone, especially those aged 14-30 years. Acne can also be interpreted as a disorder in the form of inflammation that occurs in the pilosebaceous layer in line with the accumulation and blockage of keratin material, one of which is caused by the bacterium Propionibacterium acnes (Herawati \& Amelia, 2018; Marliana et al., 2018). It causes problems for humans who want clean and smooth skin. It is evidenced by the increasing trend of using skincare among teenagers, especially skincare to prevent and treat acne.

Acne can be treated by using drugs that contain antibiotics, but drugs that are not in accordance with the rules of antibiotics will make the bacteria experience resistance (Herawati \& Amelia, 2018). For this reason, people must be very careful in choosing acne medications because drugs that are widely circulated are proven to contain synthetic chemicals, such as azelaic acid and benzoyl peroxide. Azelic acid and benzoyl peroxide can cause irritation side effects, while long-term use can cause resistance. These ingredients have a worse impact than natural ingredients (Soemarie et al., 2017).

The way that can be taken to prevent side effects from using drugs containing synthetic ingredients that can cause irritation and resistance is to use herbal ingredients for acne treatment. The benefits of herbal medicines are also diverse, such as the price is quite affordable, easy to obtain, and has fewer side effects. This reason ultimately makes people prefer this type, especially those from plants (Herawati \& Amelia, 2018; Winato et al., 2019). Even the process of processing herbal medicines is now increasingly following technological developments and what is currently being developed is the manufacture of extracts (Puspodewi et al., 2015; Zai et al., 2019).

Tamarind is an alternative plant that is used as herbal medicine from many types of plants. Tamarind is a plant commonly found in tropical areas, including Indonesia. Based on Faradiba et al., (2016), tamarind is classified as a versatile plant because the leaves, stems, fruit, and seeds can be used. However, the 
benefits of tamarind plants that are seen by the community are as a kitchen spice (Faradiba et al., 2016).

One part of tamarind that is widely used is the leaves, which can be used as cooking spices, medicinal ingredients, and also cosmetic ingredients (Lahamado et al., 2017). Antibacterial, antifungal, antiinflammatory, and antioxidant activities can be found in the extract from tamarind leaves (Judge \& Keumala, 2016). In addition, tamarind leaves also store some content such as protein, saponins, phosphorus, fat, fiber, tannins, taurine, alkaloids, flavonoids, minerals (such as sodium, potassium, magnesium, calcium), and others. Not only that, the content of secondary metabolites in tamarind leaf extract, namely flavonoids, tannins, alkaloids, and saponins can provide antibacterial properties (Nasution \& Abdifi, 2013).

Tamarind leaves contain substances that can cure various diseases and inhibit bacterial activity. According to Puspodewi et al., (2015), if tamarind leaves are processed further, such as extracted using maceration or infusion, then tamarind leaves will have antibacterial power against Salmonella typhi bacteria. Based on research results Suryadi et al., (2015), tamarind leaf liquid preparation has antibacterial activity against Escherichia coli. In addition, ethanol extract from tamarind leaves which have a concentration of $20 \%, 40 \%$ concentration, $60 \%$ concentration, $80 \%$ concentration, up to $100 \%$ concentration can inhibit the growth of Escherichia coli and Staphylococcus aureus (Multazami, 2013). However, there has been no research on the antibacterial activity of tamarind leaves (Tamarindus indica) against the bacteria Propionibacterium acnes which is the main bacteria that causes acne.

Researchers tested the effect of an ointment made from extracts from tamarind leaves on the diameter of the inhibition zone of the bacteria Propionibacterium acnes that triggers acne. According to Ulaen et al., (2012), the product in the form of an ointment was chosen because the ointment has a good consistency for skin diseases caused by bacteria. This ointment formulation is used to provide ease of use and provide the desired effect by the user. Ointment will be more suitable to be applied to acne. The active substance can also be removed by PEG-based ointment preparations better than other oil-soluble bases. This base is also suitable for acne-prone skin because it does not contain oil (Ulaen et al., 2012).

Thus, this is an effort to optimize and utilize the potential contained in tamarind leaves (Tamarindus indica) as a natural 
component in the manufacture of ointment products and conduct research on the effect of the ointment on the diameter of the zone of Propionibacterium acnes that triggers acne in the middle. increasing trend of using skincare for the prevention and treatment of acne.

\section{MATERIALS AND METHODS}

This research is a quantitative research with experimental method. The research was conducted at the Microbiology Laboratory of Biology Education and at the Central Laboratory of the Chemistry Sublab at Sebelas Maret University in August 2021 for one month. In this study, the data were presented in tabulated form and statistically analyzed using IBM SPSS Statistics 26 with One Way Anova test and followed by Post Hoc test to compare the treatment inhibition zones between test groups. Testing of antibacterial activity refers to Cahyanta \& Ardiyanti's study (2018) with modification. Preparation of ointment from ethanolic extract of tamarind leaves against Propionibacterium acnes was carried out in vitro with growth media in the form of nutrient agar by analogy measuring the diameter of the inhibition zone using a ruler. The negative sample in this study was an antibacterial test using an ointment without the addition of tamarind leaf extract, while the positive sample used an tamarind leaf extract ointment with concentrations of $25 \%, 30 \%$, and $35 \%$. The research technique consisted of 4 treatments with 20 replications. The sample in this study consisted of 5 petri dishes with 4 parts in each petri dish containing Propionibacterium acnes bacteria

\section{Preparation of Tools and Materials}

The tools needed were beaker, erlenmeyer, measuring cup, analytical balance, magnetic stirrer, stirrer bars, oven, autoclave, water bath, ose needle with round needle tip, petri dish, blender, rotary evaporator, refrigerator, ointment pot. size $30 \mathrm{cc}$, mixer, micropipette, bunsen, spirtus, cotton buds, scissors, cutter, ruler, aluminum foil, HDPE plastic Torch brand size 20x35 cm, plastic jars, plastic wrapping, markers, lighters, and paper labels. The materials needed are tamarind leaves (Tamarindus indica), bacterial culture isolate Propionibacterium acnes $100 \mathrm{ml}$ liquid media, 96\% ethanol Merck brand, 5 L aquadest, 50 grams nutrient agar for Merck brand, PEG-4000, PEG -400, nipagin, citri oleum, filter paper, disc paper, and cotton. 
Making Tamarind Leaf Extract

Extraction based on Cahyanta \& Ardiyanti's procedure (2018) with modification. Maceration method with $96 \%$ ethanol extract was used in the process of making leaf extract. The tamarind leaf simplicia powder was weighed until it reached a weight of 145 grams and soaked in $725 \mathrm{ml}$ of $96 \%$ ethanol, then stirred using a magnetic stirrer for 3 hours per day for 5 Table 1. Test Ointment Formula days. Filter paper was used as a filtration medium in both the first and second stages. The whole maserate was then concentrated using a rotary evaporator at $60^{\circ} \mathrm{C}$ with a speed of $500 \mathrm{rpm}$.

\section{Ointment Making}

Preparation of ointment based on the test ointment formula Cahyanta \& Ardiyanti (2018) in table 1.

\begin{tabular}{|c|c|c|c|c|c|}
\hline \multirow{3}{*}{$\begin{array}{c}\text { No. } \\
1 .\end{array}$} & \multicolumn{5}{|c|}{ Formula (preparation of ointment 4 grams at each concentration) } \\
\hline & Material Name & \multirow{2}{*}{$\begin{array}{c}\mathbf{F 1} \\
\mathbf{( 2 5 \% )} \\
1 \text { gram } \\
(25 \%)\end{array}$} & \multirow{2}{*}{$\begin{array}{c}\begin{array}{c}\text { FII } \\
\mathbf{( 3 0 \% )}\end{array} \\
\begin{array}{c}1.2 \text { grams } \\
(30 \%)\end{array}\end{array}$} & \multirow{2}{*}{$\begin{array}{c}\begin{array}{c}\text { FIII } \\
(\mathbf{3 5 \%})\end{array} \\
\begin{array}{c}1.4 \text { grams } \\
(35 \%)\end{array}\end{array}$} & \multirow{2}{*}{$\begin{array}{c}\text { Negative Control } \\
- \\
(0 \%)\end{array}$} \\
\hline & $\begin{array}{l}\text { Tamarind } \\
\text { extract }\end{array}$ & & & & \\
\hline 2. & PEG-4000 & $\begin{array}{c}1.16 \text { grams } \\
(29 \%)\end{array}$ & $\begin{array}{c}1.04 \text { grams } \\
(26 \%)\end{array}$ & $\begin{array}{c}0.92 \text { gram } \\
(23 \%)\end{array}$ & $\begin{array}{c}1.6 \text { grams } \\
(40 \%)\end{array}$ \\
\hline 3. & PEG-400 & $\begin{array}{c}1.8 \text { grams } \\
(45 \%)\end{array}$ & $\begin{array}{l}1.72 \text { grams } \\
(43 \%)\end{array}$ & $\begin{array}{l}1.64 \text { grams } \\
(41 \%)\end{array}$ & $\begin{array}{c}2.36 \text { grams } \\
(59 \%)\end{array}$ \\
\hline 4. & nipagin & $\begin{array}{c}0.0072 \text { gram } \\
(0.18 \%)\end{array}$ & $\begin{array}{c}0.0072 \text { gram } \\
(0.18 \%)\end{array}$ & $\begin{array}{c}0.0072 \text { gram } \\
(0.18 \%)\end{array}$ & $\begin{array}{c}0.0072 \text { gram } \\
(0.18 \%)\end{array}$ \\
\hline 5. & Oleum citri & qs & Qs & qs & qs \\
\hline
\end{tabular}

Source: Research primary data (2021)

The first step in making the ointment was to dissolve nipagin in PEG-400. Then PEG-4000 was put into a mixture of nipagin and PEG 400 on a water bath and stirred until it cooled. Tamarind leaf extract that has been made is put into the mixture and then stirred until homogeneous. Next, added oleum citri little by little in the mixture until evenly distributed. After that, the ointment was stored in the ointment pot.

\section{Nutrient Agar Media Preparation}

The growth medium was made by diluting nutrient agar 20 grams in 1 liter of distilled water in an Erlenmeyer tube, then covered with aluminum foil. The mixture was homogenized using a magnetic stirrer. Next, the mixture was sterilized using an autoclave at $121^{\circ} \mathrm{C}$. 
Growth of Bacterial Subculture Test of

\section{Propionibacterium acnes}

The test bacteria were cultured in nutrient media to make them sterile. A total of $10 \mathrm{~mL}$ of media was inoculated into sterile petri dishes and allowed to solidify. Bacterial subculture was performed with a spread plate. $0.1 \mathrm{~mL}$ of bacteria was poured using a micropipette and then flattened with a spreader.

The Potential of Tamarind Leaf Extract Ointment in Inhibiting the Growth of Propionibacterium acnes Bacteria

After pure bacterial cultures were grown on nutrient agar media, the paper discs that had been smeared with ointment from tamarind leaf extract were placed on top. Next, the media was incubated for 24 hours at a temperature of 370C. Observations and measurements of the clear zone were carried out using a ruler (Cahyanta \& Ardiyanti, 2018; Lajira et al., 2019). Tests for ointments from tamarind leaf extract used various concentrations of
$25 \%, 30 \%$, and $35 \%$. The negative control was an ointment based without tamarind leaf extract.

\section{Research and Data Collection}

The parameters tested in this study were the diameter of the inhibition zone of tamarind leaf extract ointment with different levels of extract as the independent variable and growth media in the form of nutrient agar as the dependent variable. Measuring the diameter of the inhibition zone using a ruler.

\section{RESULTS AND DISCUSSION}

The extract produced from tamarind leaves (Tamarindus indica) has a thick texture with a dark green color and weighs 10 grams. This test indicates a clear area around the disc. The area was the inhibition zone for the growth of Propionibacterium acnes bacteria which has been treated with tamarind leaf extract ointment.

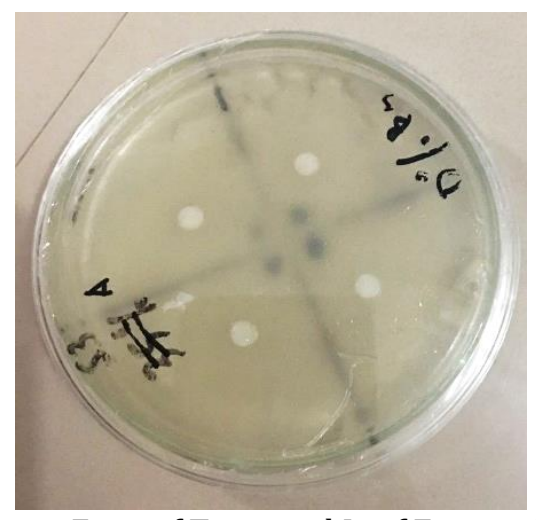

Figure 1. Inhibition Zone of Tamarind Leaf Extract Ointment (0\%) Source: Research primary data (2021) 


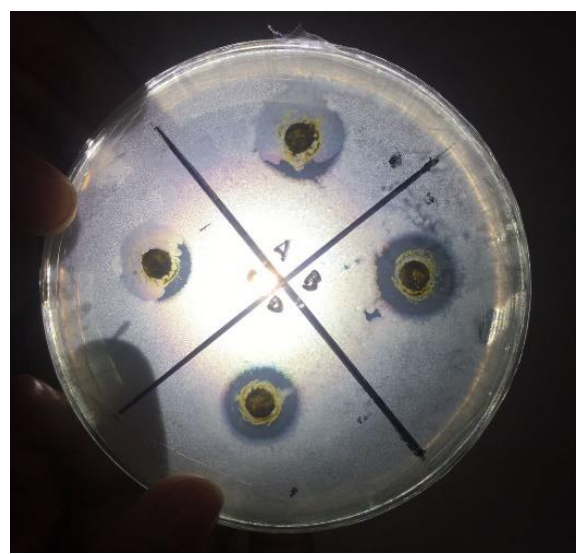

Figure 2. Inhibition Zone of Tamarind Leaf Extract Ointment (25\%) Source: Research primary data (2021)

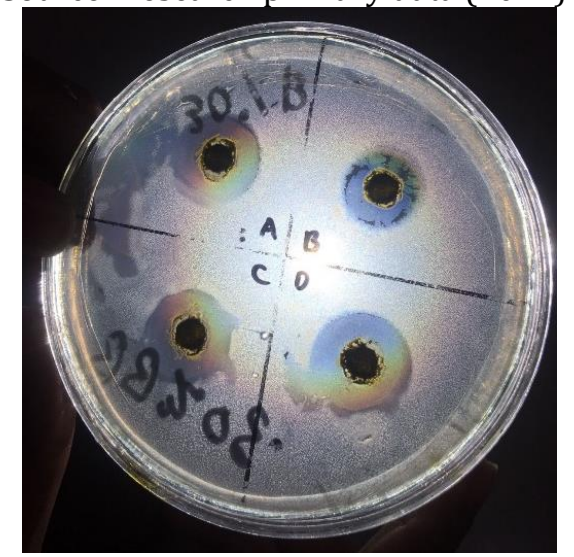

Figure 3. Inhibition Zone of Tamarind Leaf Extract Ointment (30\%) Source: Research primary data (2021)

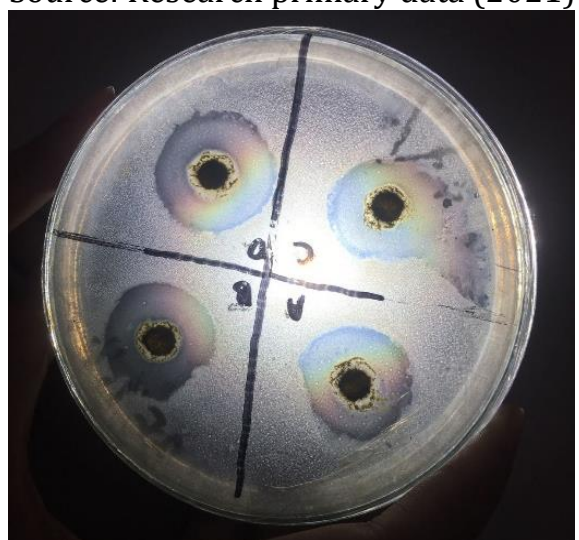

Figure 4.Inhibition Zone of Tamarind Leaf Extract Ointment (35\%) Source: Research primary data (2021)

The formulation obtained from the $\mathrm{cm}$, then formula 1 (25\%) with an average test results of the antibacterial treatment of inhibition zone diameter of $1.235 \mathrm{~cm}$. tamarind leaf extract ointment had the Measurement of the diameter of the largest inhibition zone in formula 3 (35\%) inhibition zone showed that the ointment with an average inhibition zone diameter of had a strong range of inhibition against $1,680 \mathrm{~cm}$, then formula $2(30 \%)$ with an Propionibacterium acnes bacteria. Pan et al., average inhibition zone diameter of 1.385 (2009) stated that the inhibition zone 
Azzahra, H., Shalihah, F., Trisnawati, I.N., Aeniah, S., Cahyani, L.P., \& Saputra, A. The Effect Of Tamarind (Tamarindus indica) Leaf Extract Ointment In Controlling The Growth Of The Bacteria Propionibacterium acnes That Triggers Acne

criteria were determined as follows: an area with an inhibition zone diameter of 5-10 mm that has a diameter of inhibition zone $\geq 20$ were categorized as moderate, while areas $\mathrm{mm}$ was categorized as very strong, areas with an inhibitory zone diameter of $\geq 5 \mathrm{~mm}$ with an inhibition zone diameter of 10-20 was included in the weak category. mm were categorized as strong, then areas

Table 2. Ointment Inhibition Zone Test Results

\begin{tabular}{cccc}
\hline $\begin{array}{c}\text { Obstacles } \\
\text { zone }\end{array}$ & N & Average \pm SD $(\mathbf{c m})$ & P \\
\hline F1 $(25 \%)$ & 20 & $1.235 \pm 0.2758$ & 0.000 \\
F2 $(30 \%)$ & 20 & $1.385 \pm 0.2796$ & \\
F3 $(35 \%)$ & 20 & $1.680 \pm 0.2587$ & \\
Base (0\%) & 20 & $0.000 \pm 0.0000$ & \\
\hline \multicolumn{5}{r}{ Source: Research primary data (2021) }
\end{tabular}

The test results showed that the significant value of $0.000<0.05$ so that there diameter of the inhibition zone increased in was a significant difference in the inhibition proportion to the increase in extract zone of each ointment formula. concentration. Therefore, extracts from Furthermore, the Post Hoc Tests follow-up Tamarindus indica leaves at concentrations which aims to compare the treatment of $25 \%, 30 \%$, and $35 \%$ were able to affect inhibition zones between the test groups the metabolism of Propionibacterium acnes with significant values obtained the bacteria. following results.

One Way ANOVA analysis (Table 2)

with a $95 \%$ confidence level $(\alpha=5 \%)$ had a

Table 3. Results of Post Hoc Follow-up Test Diameter of Inhibitory Zone of Tamarind Leaf Extract Ointment

\begin{tabular}{cccc}
\hline & Formula & Mean Difference(I) & Sig. \\
\hline $0 \%$ & $25 \%$ & $-1.2350^{*}$ & 0.000 \\
& $30 \%$ & $-1.3850^{*}$ & 0.000 \\
$25 \%$ & $35 \%$ & $-1.6800^{*}$ & 0.000 \\
& $0 \%$ & $1.2350^{*}$ & 0.000 \\
$30 \%$ & $30 \%$ & -0.1500 & 0.454 \\
& $35 \%$ & $-0.4450^{*}$ & 0.000 \\
& $0 \%$ & $1.3850^{*}$ & 0.000 \\
$35 \%$ & $25 \%$ & 0.1500 & 0.454 \\
& $35 \%$ & $-0.2950^{*}$ & 0.008 \\
& $0 \%$ & $1.6800^{*}$ & 0.000 \\
& $25 \%$ & $0.4450^{*}$ & 0.000 \\
\hline
\end{tabular}

Source: Research primary data (2021) 
Post Hoc follow-up test values nucleic acids, and nucleotides, so that the indicated that there was a clear difference in bacteria will undergo lysis.

antibacterial activity between the bases

with formula 1 , formula 2 , and formula 3 because $\mathrm{P}<0.05$.

The antibacterial activity of tamarind leaf extract ointment (Tamarindus indica) occurred due to the presence of compounds that had antibacterial properties, such as flavonoids which had antibacterial activity in the form of functional barriers to DNA gyrase, so that the ability to replicate bacteria was inhibited. This compound was in contact with DNA in the nucleus of sodium, bacterial cells. The difference in polarity phosphorus, calcium), and others in between the lipids that made up DNA and tamarind leaves. In addition, there were the alcohol groups in flavonoid compounds many vitamins such as thiamine (vitamin caused damage to the lipid structure of B1), pectin, riboflavin (vitamin B2), bacterial DNA so that the bacteria carotene (vitamin A), ascorbic acid (vitamin underwent lysis and died. Alkaloids as C), and niacin (vitamin B3 or B complex). antibacterial interfered with the The content of secondary metabolites peptidoglycan constituent components in contained in tamarind leaf extract in the bacterial cells so that the cell wall layer form of flavonoids, tannins, saponins, and could not be fully formed and cell death alkaloids that provide antibacterial occurred (Cahyanta \& Ardiyanti, 2018). The properties in tamarind leaves (Yunita \& next content of tamarind leaves is saponins. Khodijah, 2020).

Saponins are included in the antibacterial group that interfere with the permeability of the bacterial cell membrane so that it will damage the cell membrane and cause the release of various vital elements from the antibacterial cell in the form of proteins,

\section{CONCLUSION}

Ointment from tamarind leaf extract with concentrations of $25 \%, 30 \%$, and $35 \%$ was proven to have antibacterial activity against Propionibacterium acnes bacteria. The results of the calculation of the 
Azzahra, H., Shalihah, F., Trisnawati, I.N., Aeniah, S., Cahyani, L.P., \& Saputra, A. The Effect Of Tamarind (Tamarindus indica) Leaf Extract Ointment In Controlling The Growth Of The Bacteria Propionibacterium acnes That Triggers Acne

diameter of the inhibition zone stated that

the ointment from the extract of the leaves

of tamarind (Tamarindus indica) had a

strong category of inhibition against the

bacteria Propionibacterium acnes.

\section{ACKNOWLEDGEMENT}

The researcher would like to thank

the supervisors, the Biology Education study program at Sebelas Maret University, and all parties who support this research.

\section{REFERENCES}

Cahyanta, A. N., \& Ardiyanti, N. Y. (2018). Uji Aktivitas Salep Anti Jerawat Ekstrak Etanol Daun Binahong (Anredera cordifolia (Ten Steenis)) terhadap Bakteri Propionibacterium acnes. Parapemikir. Parapemikir: Jurnal Ilmiah Farmasi: 7(2), 239.

Faradiba, A., Gunadi, A., Praharani, D., \& Kalimantan, J. (2016). Daya Antibakteri Infusa Daun Asam Jawa (Tamarindus indica Linn) terhadap Streptococcus mutans (Antibacterial Activity of Asam Jawa Leaf Infuse (Tamarindus indica Linn) against Streptococcus mutans. E-Jurnal Pustaka Kesehatan: 4(1), 55-6o.

Hakim, R. F., \& Keumala, C. N. (2016). Pengaruh Daun Asam Jawa (Tamarindus indica Linn) Terhadap Pertumbuhan Candida albicans. Journal Of Syiah Kuala Dentistry Society: 1(1), 29-34.

Herawati, E., \& Amelia, T. (2018). Potensi Bahan Herbal Ekstrak Etanol Daun Mengkudu Asal Desa Wajak Lor, Tulungagung, Jawa Timur Terhadap Bakteri Penyebab Jerawat. JuKe (JuKe (Jurnal Kesehatan): 2(2), 173-178.

Lahamado, O. T., Sabang, S. M., \& Mustapa, K. (2017). Ekstrak Daun Asam Jawa (Tamarindus indica L.) Sebagai Antidiabetes. Jurnal Akademika Kimia: 6(1), 1.

Lajira, M., \& Ehrich Lister, I. (2019). UJI ANTIBAKTERI EKSTRAK BUAH TAKOKAK (SOLANUM TORVUM SWARTZ) TERHADAP PERTUMBUHAN BAKTERI PROPIONIBACTERIUM ACNES. BIOLINK :
Jurnal Biologi Lingkungan Industri $\begin{array}{llll}\text { Kesehatan, } & 6(1), & 73 & -\end{array}$ doi:https://doi.org/10.31289/biolink.v6i1.223 7

Lestari, R. T., Gifanda, L. Z., Kurniasari, E. L., Harwiningrum, R. P., Kelana, A. P. I., Fauziyah, K., Priyandani, Y. (2021). Perilaku Mahasiswa Terkait Cara Mengatasi Jerawat. Jurnal Farmasi Komunitas: 8(1), 15.

Marliana, M., Sartini, S., \& Karim, A. (2018). EFEKTIVITAS BEBERAPA PRODUK PEMBERSIH WAJAH ANTIACNE TERHADAP BAKTERI PENYEBAB JERAWAT Propionibacterium acnes. BIOLINK : Jurnal Biologi Lingkungan Industri Kesehatan, 5(1), 31-41. doi:https://doi.org/10.31289/biolink.v5i1.166 8

Multazami, T. (2013). Uji Aktivitas Antibakteri Ekstrak Etanol Daun Asam Jawa (Tamarindus indica L.) Terhadap Staphylococcus aureus ATCC 6538 dan Escherichia coli ATCC 11229. Naskah: 66(1997), 37-39.

Nasution, H., Nst, M. R., \& Abdifi, R. (2013). Aktivitas Antidiabetes Ekstrak Etanol Daun Asam Jawa (Tamarindus indica Linn) terhadap Enzim Alfa Glukosidase. Photon: Jurnal Sain dan Kesehatan: 4(1), 71-75.

Pan, X., Chen, F., Wu, T., Tang, H., \& Zhao, Z. (2009). The Acid, Bile Tolerance and Antimicrobial Property of Lactobacillus acidophilus NIT. Food Control. 20(6): 598602.

Puspodewi, D., Darmawati, S., \& Maharani, E. T. (2015). Daya Hambat Daun Asam Jawa (Tamarindus indica) Terhadap Pertumbuhan Salmonella typhi Penyebab Demam Tifoid. The 2nd University Research Coloquium 2015, 2(2009): 45-50.

Soemarie, Y. B., Astuti, T., \& Rochmah, N. (2017). Formulasi Sediaan Salep Ekstrak Etanol Daun Alpukat (Persea americana Mill.) Sebagai Antiacne. Jurnal Ilmiah Manuntung: 2(2), 224 .

Suryadi, C., Rusmana, D., \& Evacuasiany, E. (2015). In Vitro Antimicrobial Activity of Javanese Tamarind Leaves Infusion (Tamarindus indica Linn.) in Escherichia coli. Journal of Medicine and Health: 1(1), 41-47.

Ulaen, S., Banne, Y., \& Suatan, R. (2012). Pembuatan Salep Anti Jerawat dari Ekstrak Rimpang Temulawak (Curcuma xanthorrhiza Roxb.). Jurnal Ilmiah Farmasi Poltekkes Manado: 3(2), 96587. 
Utami, N. W. B., \& Krisnandika, A. A. K. (2016). Pendekatan Fisik dan Ekologis Penggunaan Pohon Asam Jawa Sebagai Tanaman Tepi Jalan di Sekeliling Trotoar Lapangan Puputan Badung, Denpasar. E-Jurnal Arsitektur Lansekap: 2(2), 177-186.

Winato, B., Sanjaya, E., Siregar, L., Fau, S., \& Mutia, d. (2019). UJI AKTIVITAS ANTIBAKTERI EKSTRAK DAUN SERAI WANGI (CYMBOPOGON NARDUS) TERHADAP BAKTERI PROPIONIBACTERIUM ACNES. BIOLINK : Jurnal Biologi Lingkungan Industri Kesehatan, 6(1), 50 - 58. doi:https://doi.org/10.31289/biolink.v6i1.221 o
Yunita, E., \& Khodijah, Z. (2020). Pengaruh Konsentrasi Pelarut Etanol saat Maserasi terhadap Kadar Kuersetin Ekstrak Daun Asam Jawa (Tamarindus indica L.) secara Spektrofotometri UV-Vis. PHARMACY: Jurnal Farmasi Indonesia (Pharmaceutical Journal of Indonesia): 17(2), 273-280.

Zai, Y., Kristino, A., Ramadhani Nasution, S., \& Natali, O. (2019). UJI EFEKTIVITAS ANTIBAKTERI EKSTRAK DAUN SIRSAK (ANNONA MURICATA LINN.) TERHADAP BAKTERI PROPIONIBACTERIUM ACNES. BIOLINK : Jurnal Biologi Lingkungan Industri Kesehatan, 6(1), 65 - 72. doi:https://doi.org/10.31289/biolink.v6i1.224 4 